\title{
Buddhist Education Management in Peking University
}

\author{
Poonam Kumari \\ School of Humanity and Law \\ Northeastern University \\ Shenyang, China
}

\author{
Wanbing Shi \\ School of Humanity and Law \\ Northeastern University \\ Shenyang, China
}

\begin{abstract}
Purpose: The purpose of this paper is to find out about the management of Buddhist education, Teaching and Research, Faculties, and Administration and Finances of Peking University. Design/ methodology/approach: Peking University has been offering courses and conducting research in the field of Buddhist Studies. It has made significant achievement in developing Buddhist studies, yet there are some issues that exist. Here we analyze the issues and the effects of existing Buddhist higher education for management and development of the Peking research University. Findings: This paper has analyzed the current situation of the Buddhist education management in the Peking University, with reference to management of Buddhist education, faculties, teaching and research, finance and administration. Originality/value: The main value of this paper is about the development of the Buddhist higher education which has spread the teaching and research all over world. According to us, there was no research done on this topic.
\end{abstract}

Keywords-Peking University; Buddhist education; administration and management

\section{INTRODUCTION}

Peking University was founded in 1898 and primarily known as an imperial University of China. The Peking University was the first national University covering extensive disciplines in China. Since its establishment, the Peking University has been a leading institution of higher education in China, and it also provided the highest administration to education in the beginning of its establishment. [1][2]

The Philosophy Department of the Peking University was established in 1912, "initially named the Philosophy portal". Enrollment in the Chinese Philosophy Department was the earliest in 1914, marking the beginning of modern Chinese Philosophy, and nearly ten thousand students have graduated from this Department. According to the history of the Peking University, many famous scholars used to teach in the Department of Philosophy. And they taught generations of the best Chinese Philosophers and made the department a cradle of the modern Chinese Philosophy. Before 90 years, faculty members of the Philosophy department have presented a great deal of academic masterpieces. [3]
Many other Philosophy departments were started in China in 1952 and joined the Philosophy department of the Peking University, because of the national adjustment of the departments. In 1978 the psychology unit was separated from the Department of philosophy, and became the Department of Psychology.

The Department of Philosophy developed expeditiously in 1978 with several reforms and has come to be known outside as well. All fields were established in the Philosophy Department, and faculty, board, and library resources were developed and enriched. Simultaneously, conditions for scientific research were improved significantly. There are nine courses of studies in the Philosophy Department in the Peking University: Marxist Philosophy, Chinese Philosophy, Foreign Philosophy, Logic, Ethics, Aesthetics, Buddhism and Taoism, Christianity and Religious Studies, and Philosophy of Science. [4]

\section{DEPARTMENT OF BUDDHISM AND TAOISM}

The Department of Buddhism and Taoism was established on the basis of the earlier Department of Oriental Philosophy and Department of the Religious Studies. The teaching and research section was established in 2000, by the first director of the teaching and research Professor Li, and the present director of the teaching and research Professor Yao Weiqun. There are currently six teachers in the section of teaching and research. All the teachers teach courses related to Buddhism Philosophy and Taoism. For example, Professor Li Weilong specializes in the study of Chinese Buddhism and Philosophy, Associate Professor Zhou Xuenong teaches History of Chinese Buddhism and Modern Buddhist Studies, Wang Song is related to Study of Buddhism and Oriental Philosophy, Associate Professor is mainly related to Chinese Buddhism and Japanese Buddhist Studies, and Associate Professor Cheng Lesong teaches Taoist History and Taoist Classics Research. [5]

\section{BUdDHIST STUdIES MANAGEMENT}

Buddhist Studies in the Peking University are centered in the Departments of Philosophy, and of Religious Studies, but not as a college. There are similar style approaches of Buddhist Studies, method and attitude in this University are similar to any other Buddhist University. The most significant aspect of study in the Peking University is that 
there is no uniform style for all students who study in Buddhist studies. The Peking University is compatible with the package, good environment, academic freedom in the profession, research and in the specific presentation, according to the principles of Cai Yuanpei. [6]

\section{A. Study Program Management in Buddhist Studies}

There are two types of Study programs in the Buddhist Studies, Post Graduate Program and Ph.D.

\section{1) Ph.D. program management}

- Time of Duration - After Master's degree the duration period is 4 years, but in particular cases students can reduce or extend the duration of study upon application after completion of more than 2 years. Direct study of Ph.D. degree for Graduate students (referred to as straight students), and the longest study period of Ph.D. students, is 8 years and the longest period of study is calculated from the beginning of their Master's degree. According to the regulation of the degree committee, students are required to fulfill a designated number of credits, conduct research, complete writing a Ph.D. Thesis, defend it in front of a panel of experts.

- Admission - Students should be non-Chinese citizens with a valid passport for admission into Ph.D. A student should have acquired Bachelor's degree and Master degree for admission into Ph.D. [7]

- Curriculum - The history of Indian Buddhism, The history of Chinese Buddhism, The selection of Chinese Buddhist scriptures, The history of Chinese religion, The selection of Indian Buddhist scriptures, The selection of ancient Indian Philosophy, Buddhism in Europe and the United State.[8]

- Credit Requirements for Ph.D. Program - The Ph.D. Courses are provided for the corresponding credits, easement results qualified, to obtain the appropriate credits and records on the report. The method of calculating credits is generally done in class Hours. The Ph.D. students are required to score 70 points for the qualified course examination, and 60 points for the qualified required elective courses. Direct study of Ph.D. degree for Graduate students (referred to as straight students) should read a total score of not less than 40 credits, Master's starting point for Ph.D. Degree should be less than 18 credits.

- Ph.D. Thesis - Thesis should be completed by the $\mathrm{Ph} . \mathrm{D}$. students under the guidance of the instructor and steering group. This should be a completely creative academic paper or a group of essays. According to the rules of the Peking University for Ph.D. students need to have at least two accepted/published papers in the domestic core journals or international publications. [9]

2) Master's degree program management

- Time of Duration - The time of duration period is three years (or in some cases two years), for Buddhist
Studies in the Master's Degree program. According to the regulations of the Degree Committee students should be qualified with a designated number of credits, complete the Master's thesis and defend of it in front of the panel of experts. And then students will receive a graduation certificate along with the Master's Degree.

- Admission - The students must be interested in Buddhist culture of learning and research with good practice, abide by the national laws and regulations, good practice. A student should be qualified with a Bachelor's degree and after graduation work for more than three years and students must submit the Buddhist research papers of more than 3000 words, as an admission qualification assessment.[10]

- Curriculum and Credits - Required courses (6 out of credits 24): Religious research methods, the history of Indian Buddhism, History of Chinese Buddhism, Selected Buddhist Classics in India, Selected Chinese Buddhist Books and Buddhist sectarian topics. Elective Courses (4 out of 6 credits): The theme of modern Buddhism, Tibetan Buddhism, Asian Buddhism and Chinese folk religion. [11][12]

\section{TEACHING AND RESEARCH MANAGEMENT}

Teaching - The teaching and research in Buddhism has made great achievements, opened a large number of courses, published many high level works, access to a number of provincial and ministerial level scientific research awards. Important research topics that have been completed and are being carried out, as Indian philosophy, early Quan zhen study, European and American Buddhist academic history research, Chinese Buddhist studies, Indian Brahmanism philosophy and Buddhist philosophy comparative study, Japanese modern Buddhist reform ideological significance.

Research - In November 2010 the Buddhist education research center was established in the Peking University of China, the research department was based in the Department of Religious Studies. The department has set up its domestic and foreign Buddhist higher education. And its related fields of academics have the exchange platform for an integration of national higher education and religious education system, for expansion into a new period of Buddhist educational curriculum system and teaching methods. Since its beginning a center has assisted the Buddhist school of Shenzhen Dharma Temple for developing teaching plans, curriculum of study system and teachers training. The center has published a humanities and religious studies. And in March 2012 the Buddhist literature, history and philosophy workshop has been set up for the cutting-edge platform to the young and middle-aged Buddhist scholars.[13]

\section{AIM OF BUDDHIST DEPARTMENT}

Develop Buddhism on the basis of solid foundation, develop the master theory of religion, familiar with the relevant religious policy professionals, to help students improve the cultural literacy of Buddhism and expand their 
horizons, with particular emphasis on the combination of theory and practice.

\section{BUDDHIST DEPARTMENT MANAGEMENT}

There are four faculty members in the Buddhist Studies Department of the Peking University, three professors and one associate professor.

- Fields for Professors - Buddhism, Oriental Philosophy, History of Chinese Buddhism, Buddhist Philosophy, and Chinese Buddhism and Japanese Buddhism.

- Field for Associate Professor - History of Chinese Buddhism and Modern Buddhism. ${ }^{[14]}$

- Administration - Dean, Vice dean, Dean assistant and Secretary.

\section{FINANCIAL MANAGEMENT FOR STUDENTS}

There are many sources of financial support for students in the Peking University, but the financial support is not equal for the Chinese students and foreign students.

The details of financial support for the Chinese and foreign students are:

- PKU Annual Scholarship: Every year the Peking University provides PKU Annual Scholarship for excellent Chinese students, such as Zhong Ying scholarship, Guang Hua scholarship, Liao Kai yuan scholarship and national scholarship.

- Han Kun Youth Legal Scholarship: This scholarship is available only for brilliant Chinese students, and the Baosteel Taiwan, Hong Kong and Macau Scholarship to outstanding students.

- Grants : China star light charity fund also supports students.

- Banks : National Bank and Commercial Bank also provide education loan for Chinese students.

- Other Financial Resources : Students research assistant program and students general assistant program are also available.

- Financial Support for International Students: For international students there are many scholarships in the Peking University. Like the Chinese Government Scholarship (CSC), Chinese Local Government Scholarship, Confucius Scholarship, Peking University Scholarship, and Enterprise Scholarship. ${ }^{[15]}$

\section{CONCLUSION}

It can be clearly seen that the Peking University of China has made significant contribution to the higher education in the world. There is no special department for the Buddhist Studies in the Peking University, but Buddhist Studies is a special part of the Philosophy and Religion department. The Peking University of China also focuses on the higher education, and the Buddhist higher education was developed by the Philosophy and Religion department.

There have been some internal problems about the Buddhist education management, such as education management, students' management, and faculties' management. The Peking University of China is also developing the Buddhist Education Research Center that is based in the Separtment of Religious Studies.

\section{REFERENCES}

[1] History Peking University. Retrieved 15 July 2015.

[2] http://www.chinaeducenter.com/en/university/pku.php

[3] Zhang Xiaoheng. (Peking University Philosophy Course), China Theater Publishing House; 1st edition, July 1, 2011 (M)page no 1)

[4] https://www.phil.pku.edu.cn/

[5] Song Wenjian. Reform of the Logic Compulsory Course in the Philosophy Department of Peking University [J]. Domestic Philosophy, 1986-07-30

[6] https://www.phil.pku.edu.cn/teacher.php?op=rom\&rm=7

[7] http://english.pku.edu.cn/Admission/InternationalStudents/GeneralInf ormation/

[8] http://www.fjnet.com/kuaixun/201005/t20100505_154133.htm

[9] http://english.pku.edu.cn/Admission/InternationalStudents/GeneralInf ormation/

[10] http://english.pku.edu.cn/Admission/InternationalStudents/GeneralInf ormation/

[11] http://www.fjnet.com/kuaixun/201005/t20100505_154133.htm

[12] http://english.pku.edu.cn/Admission/InternationalStudents/GeneralInf ormation/

[13] http://en.phil.pku.edu.cn/research

[14] http://en.phil.pku.edu.cn/research

[15] http://stl.pku.edu.cn/admissions/financial-information 